\section{Professional Development and Sustainable Development Goals}

Peni Hausia Havea ${ }^{1}$ and Manoranjan Mohanty ${ }^{2}$

${ }^{1}$ Pacific Centre for Environment and Sustainable

Development, The University of the South

Pacific, Suva, Fiji

${ }^{2}$ Development Studies, The University of the

South Pacific, Suva, Fiji

\section{Synonyms}

Continuing education; Occupational advancement; Professional advancement; Professional competences; Professional growth; Professional learning; Upskills training

\section{Definition}

Professional development is defined as a consciously designed systematic process that helps professionals to attain, utilize, and retain knowledge, skills, and expertise. It is simply a process of obtaining skills, qualifications, and experience that help in advancement in one's career. In the field of education, it is defined as the process of improving staff skills and competencies needed to produce outstanding performance of students. It also refers to a process of improving an organization's staff capabilities through access to education and training opportunities for better output. Professional development can include a variety of approaches such as formal and informal education, vocational, specialized, or skill-based training, or advanced professional learning.

\section{Introduction}

In this entry, the concept of professional development is explained covering briefly its history, types, processes, benefits, and framework. At the outset, the concept of professional development is defined.

Professional development through education and training increases the capabilities of individuals and improve the productivity of the workforce. It enhances the quality of workforce in different sectors including education, health, economic, environment, and human rights. It thus helps to build sound human resource development of a country, a foundation for sustainability. A lack of professional development will jeopardize the achievement of SDGs as set under the 2030 Development Agenda.

Professional development is discussed in this entry in the context of the Sustainable Development Goals (SDGs) which are divided under five 
main sectors: education, health, economic, environment, and human rights. Because of the significance of these sectors to peace and prosperity of the people, professional development is, therefore, a blueprint to the achievements of the 17 SDGs by developed and developing countries, via a global partnership, by 2030. Sustainable Development Goal 4 focuses on the theme "Quality Education" under the heading, "Ensure inclusive and equitable quality education and promote lifelong learning opportunities for all." Professional development in education can not only enhance quality education but also can help meeting the targets and SDGs.

In terms of the content arrangement, the main text is organized into nine sections. Section "Introduction" deals with a general introduction. Section "Professional Development" focuses on the concept of professional development covering its history, types, processes, benefits, and framework bringing linkages between sectors and Goals, thus providing a model linking them to targets and indicators in achieving a resilient and sustainable professional development. Section "Approaches to Professional Development" deals with approaches to professional development. Section "Professional Development in Five Key Sectors" covers professional development in five sectors such as education, health, economic, environmental, and human rights. Section "Factors Affecting Contemporary Trends in Professional Development" highlights the factors affecting contemporary trends in professional development. Section "Professional Development and Sustainable Development" discourses professional development and sustainable development. The section also highlights the progress so far made in the professional development section and the SDG Goals. Section "Challenges to Professional Development" outlines the associated challenges inflicted the professional development in the achieving of the SDG by 2030 . Section "Way Forward" unravels the future directions that would be used to guide the implement the SDG framework by 2030 and beyond. Lastly, section "Conclusion" summarizes the chapter with a conclusion.

\section{Professional Development}

The following section deals professional development covering its history, types, processes, and benefits.

\section{History}

Professional development was originated and came overwhelmingly into inevitably forced in the United States of America in the 1960s (Murphy-Latta 2011). It was designed as a critical part of a professional development program for school staff in the American education system. Since then, professional development emerged as a worldwide tool for both personal and professional growth and development not only in the education sector but in other disciplines as well. For example, many authors pointed out that professional development contributed significantly to the overall health care provided by physicians, dentists, nurses, IT professionals, and other allied health care personnel, thus helping in improving the health and well-being and quality of life (Ayeleke et al. 2016; Smith and Johnson 2018). From the SDG perspective, professional development is not only applied to the development in the education and health sector but also in the other disciplines such as the environment, economic, and human rights. As a result, sustainable human resource development is of great importance to the milestone of SDGs, whether locally, nationally, regionally, or internationally (Chams and García-Blandón 2019). Historically, this is vital because, without professional development, SDG Agenda may not be achieved by 2030 in building a pathway which is more resilient and sustainable.

\section{Types}

The literature indicated that professional development (PD) opportunities supporting the SDGs are folded into two main categories: informal and formal (OECD 2009). Informal professional development includes education and training in which no proper qualification is awarded, and it is generally done by individuals (e.g., self-education and learning). The other form of professional 
development is through a formal qualification (e.g., universities) (OECD 2009; ICSA 2019). Formal types include vocational education leading to qualification or credential. Professional development may also in the form of in-service PD programs which may be formal or informal. Professional development on the job may develop or enhance process skills, sometimes referred as "leadership skills" or "task skills," and some examples for process skills are "effectiveness skills," team functioning skills, and "systems thinking skills" (Garet et al. 2001). Both types of professional development require personalcritical investment in oneself and ongoing learning. The "state-of-the-art idea" is that if there is always something new to learn, then one must have an open mind to do it whether formally or informally. Through quality education and professional development, SDG is achievable by 2030.

\section{Processes}

Professional development was founded on the principle of adult learning theory, which explains professional development process in six steps in a cycle, i.e., sustain, design, promote, deliver, follow-up, and evaluate (Fig. 1).

The six steps involved in a professional development process are described in Table 1.

Using this process as a guide, an effective and efficient professional development program is the one that actively engage in human resource development through planning, designing, marketing, delivering, following up, and evaluating of the professional development offerings. From a sustainability point of view, the six steps are vital in providing a resilient and sustainable profession development service to personnel in education, health, economic, environmental, and human rights sectors, worldwide.

\section{Benefits}

The main goals of professional development are to increase one's knowledge and skills. Apart from increasing knowledge, skills, and competency, professional development brings in competitive advantages, increase employability and earning potential, increase efficiency, and build professional credibility. Broadly, there are three

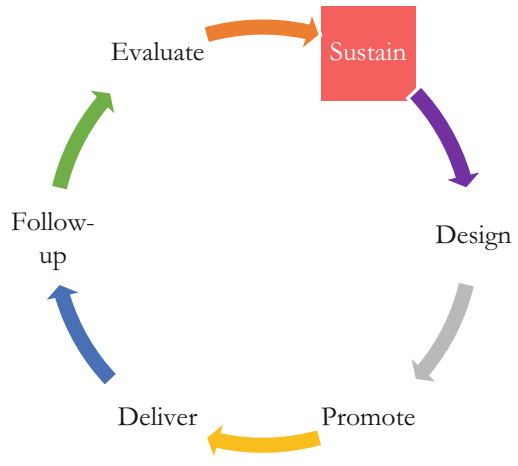

Professional Development and Sustainable Development Goals, Fig. 1 Professional development processes. (Source: CDC 2018)

Professional Development and Sustainable Development Goals, Table 1 Steps in professional development process

\begin{tabular}{l|l}
\hline Steps & Description \\
\hline Sustain & $\begin{array}{l}\text { Sustain an effective and efficient } \\
\text { infrastructure that merits professional } \\
\text { development }\end{array}$ \\
\hline Design & $\begin{array}{l}\text { Design effective and proficient professional } \\
\text { development activities diligently }\end{array}$ \\
\hline Promote & $\begin{array}{l}\text { Promote state-of-the-art strategies to } \\
\text { establish and sustain significant contacts and } \\
\text { provide high-quality services }\end{array}$ \\
\hline Deliver & $\begin{array}{l}\text { Deliver activities in a timely and systematic } \\
\text { manner }\end{array}$ \\
\hline Follow- & $\begin{array}{l}\text { Follow-up to support personal growth and } \\
\text { development to meet professional goals }\end{array}$ \\
\hline up & $\begin{array}{l}\text { Evaluate for continuous improvement, } \\
\text { excellence performance, and continuing } \\
\text { education for further professional } \\
\text { development }\end{array}$ \\
\hline
\end{tabular}

Source: CDC (2018)

major areas of benefits through professional development: sociocultural, economic, and political benefits. There are reasonably several tangible sociocultural benefits for effectively engaged in professional development under the auspices of the SDGs. First, it has benefitted people personally (Wilson et al. 2019). It is what James Froude (2014) called the nemesis of faith, meaning, "You cannot dream yourself into a character; you must hammer and forge yourself one." This is 
especially true in the sense that responsible people who are investing wisely in building themselves first are invariably tending to naturally build their level of confidence to grow remarkably and excel professionally at a personal level. Because of this, others (e.g., colleagues) could benefit tremendously from this proficient level of personal expertise timely, systematically, and diligently (Wilson et al. 2019).

Second, people are undoubtedly benefiting from professional development due to marketing principle and a sense of professionalism. From what is conventionally known in the empirical literature is that the standard of professionalism is one of the key factors for vertical mobility (Maclean 1992). As a result, lifelong learners are engaged in professional development opportunities in a peculiar sense that they genuinely want to become more professional (e.g., boosting ultimate confidence, skills, and competency) and/or to proportionately increase their executive ranks in the hierarchy (Aslam et al. 2017). Third, political leaders have utilized professional development entities into what Silvester and Wyatt (2015, p. 370) called the "routes to power" meaning not only that leaders utilize it to assist them to develop strong and diverse political leadership skills but also their management acumen. As a consequence, although some prominent politicians, as Silvester and Wyatt (2015, p. 370) said, are traditionally hubris (i.e., "I'm elected, so who are you to tell me I need training?") about carefully introducing philosophical training to politics, empirical evidence suggested that the functional benefits were enormous (Lewis 2016). Fundamentally, this strategy should be supported with a view to prevent politicians from twisting science or other nuances for political purposes (Lewis 2016). Baldwin (2017) said, the net result is that "when politicians listen to scientists, we all benefit" from it.

Furthermore, a theological perspective has also emerged that says, professional development benefits religions by helping to address religious diversity (Subedi 2006). Duffy et al. (2010) accentuated on this point by calling on all employers to respect people's religious faith and spirituality because these make them closer to
God, hence improving their physical, mental, and spiritual well-being. This explains why happiness has a direct correlation to better performance in workplaces and other fundamental attributes (Proto 2016). Another critical benefit is that because people study more about the scriptures, as a corollary it is expected that they should foster a more thorough understanding about their religions so that they should be capable of serving their God well regardless of their faith (Havea 2019). Moreover, professional development produces a social benefit (Nilsson 2010; Donelan 2016). Not only it provides a platform for creating networks with people of diverse backgrounds but also creates window of opportunities to get to know new people with multi-specialists, which will benefit themselves in the long-run. For example, the data revolution is already happening worldwide in the professional realm, hence there are dramatic changes about how people think about using real-time data and statistics for monitoring and decision-making purposes (Van den Homberg and Susha 2018; Honeck et al. 2018; Giezen et al. 2018; Körfgen et al. 2018). Additionally, professional development has economic benefits. According to many scholars, professional development can come in the form of rewards in terms of monetary value; consequently, benefitting people economically (Ionela 2012; EvoLLLution 2012; Blau et al. 2016; Opperman et al. 2018).

EvoLLLution (2012) conducted a study of 200 employers across North America to understand their perceptions on continuing education and professional development and concluded that:

- $96 \%$ of employers indicated that professional development (e.g., continuing education) had improved job performance.

- $87 \%$ of employers have influenced wages positively (e.g., pay rise).

- $78 \%$ factored professional development (e.g., continuing education) into promotions.

- Companies supporting employee education for advancement can mitigate turnover costs associated with outside hires, thereby saving money and increase efficiency. 
- $70 \%$ indicated that employees needed professional development (e.g., continuous learning) with the intention to sustain the demands of their present employment.

Because of these indispensable linkages between professional development and economic growth and development, there is a long-term benefit from professional development to the world's economy (Nilsson 2010).

Last but not the least, professional development opportunities also have positive implications and benefits to human health. Kamlesh Giri, a multi-specialist homoeopathic physician from India argued strongly that professional development impacted the health of the community positively (e.g., better health care services and health outcomes). Giri et al. (2012) recommended, because of its health benefit, professional development should be an integral part of staff development in the health sector. Most importantly, Smith and Johnson (2018) believed that professional development is the best practice for sustainable and resilient health because it guaranteed the patient's good health and safety.

\section{Framework}

The professional development framework for this entry is guided by 17 SDGs, which are categorized under five sectors: education (SDG 4), health (SDG 2, 3, and 6), economic (SDG 1, 8, 9, and 12), environment (SDG 7, 11, 13, 14, and 15 ), and human rights (SDG 5, 10, and 16). However, the only exception is SDG 17 , which is designed to be independent since it has linked to all 16 Goals via a global partnership (Fig. 2). All sectors need to come together in a framework to guide the implementation of the SDGs. Figure 2 is showing a framework for sustainable professional development under the auspices of SDGs.

\section{Approaches to Professional Development}

There is no single best approach to professional development. A combination of approaches for different situations may lead to a successful professional development. There are several approaches used in professional development in different sectors. Professional development can be developed through various means ranging from informal dialogue, reading professional literature, observations to a more sophisticated one such as courses and workshops, conferences and seminars, professional development networking, individual and collaborative research and peer education, and qualification programs (OECD 2009). Other examples of approaches to professional development include, case study method, consultation, coaching, communities of practice, lesson study, mentoring, reflective supervision, and technical assistance (NPDCI 2008).

There are several approaches to improve or enhance sustainable human resource management so as to achieve the 2030 Development Agenda. Smith et al. (2017) in a study on professional development leaders in several States in America using a mixed method found that a reform-based professional development program would be the best approach to develop education, health, economic, environmental, and human rights sector to achieve SDGs by 2030. According to Smith et al. (2017), these professional development approaches can be applied to all sectors and are categorized as:

(a) Single episode expert-led group-based (e.g., training, conference)

(b) Single episode expert-led individual-based (e.g., certification)

(c) Single episode learner-centered group-based (e.g., retreat)

(d) Single episode learner-centered individualbased (e.g., self-exploration)

(e) Series of episodes expert-led group-based (e.g., class, multiple workshops)

(f) Series of episodes expert-led individual-based (e.g., online course, apprenticeship)

(g) Series of episode learner-centered groupbased (e.g., lesson study, community of practice)

(h) Series of episodes learner-centered individual-based (e.g., mentoring, coaching, peer education) 


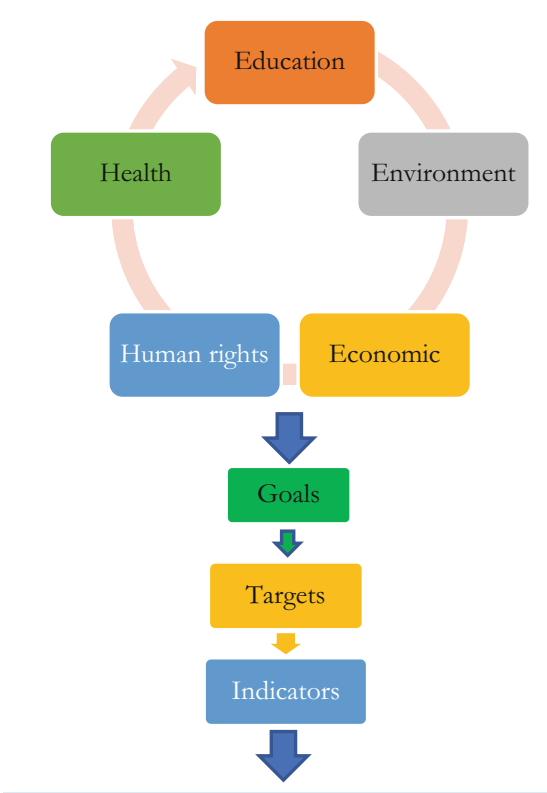

Sustainable Professional Development

Professional Development and Sustainable Development Goals, Fig. 2 Framework for sustainable professional development under the auspices of SDGs. (Source: Havea and Mohanty based on data from UNDP (2015))

This approach was used by Fernandez (2002) in Japan and Arslan (2019) in Turkey, in an attempt to achieve better resilient and sustainable professional development, and their work was found to be consistent with that of Smith et al. (2017) (Coenders and Verhoef 2019).

\section{Professional Development in Five Key Sectors}

The following section deals with professional development in five key sectors such as education, health, economy, environment, and human rights.

\section{Professional Development in Education}

The professional development in education that is widely used focussed mainly on two major areas: teachers' professional development and professional development in special education.
Professional Development of Teachers

Professional development of teachers is critical in improving student's learning. Teacher professional development is defined as "teachers' learning: how they learn to learn and how they apply their knowledge in practice to support pupils' learning" (Postholm 2012). In education sector, the professional development are conducted in the form of a wide variety of specialized training, formal education, or advanced professional learning intended to help administrators and teachers, improve their skill, professional knowledge, competence, and effectiveness. Gusky and Huberman (1995) argued, "Never before in the history of education has greater importance been attached to the professional development of educators" (p. 3). There has been a paradigm shift from traditional professional development in education. As Stein et al. (1999) said "The new paradigm for professional development represents clear departure from the use of workshops to teach, techniques' toward the use of multiple professional development strategies to build teacher capacity to understand subject matter, pedagogy, and student thinking" (p. 263).

Professional development of teachers in order to achieve quality education by 2030 is always with education for sustainable development. Whether teachers' profession is in education, health, environment, economic, or human rights, it is predicted that they play a critical role in achieving the 2030 Development Agenda (Gore et al. 2017). For example, a study on Education for Sustainable Development (ESD) in the thirdyear degree program for teachers $(n=16)$ in Early Childhood Education (ECE) at the Universitat Internacional de Catalunya in Spain showed that integrating sustainability into Higher Education Curricula (HEC) improved the idiosyncratic competence on SDGs (Fuertes-Camacho et al. 2019). Fuertes-Camacho et al. (2019) recommended that such professional development program should be implemented worldwide in the professionalization of preschool and primary school teachers. Sexana (2012) noted that teacher training programs benefitted their students and gradually add strength to school education. 
Professional Development in Special Education

The Goals also apply to all the vulnerable people including persons with disabilities through a simple virtue of inclusive education and vocational training at all levels. The United Nations Convention on the Rights of Persons with Disabilities (CRPD) as a guiding framework for the implementation of the SDGs has ensured the vulnerable population including persons with disabilities and special needs to quality education is adequately addressed. To corroborate this point, a study on children with disabilities and their right to education in Madagascar showed that professional development in special education contributed significantly to the achievements of SDGs (Education Development Trust 2016). Subsequently, they recommended that such professional development program in special education for children with disabilities should be adopted by relevant stakeholders, globally (Education Development Trust 2016).

\section{Professional Development in Health}

Professional development in health care is fundamental that encompasses activities that health care professionals need to maintain, develop, and enhance their skills, knowledge, and attitudes with an eye to stay up-to-date with the state-ofthe-art device, idea, or skills for disease control and prevention, as part of its pledge to meet the 2030 Development Agenda (Nunes et al. 2016). Nunes et al. (2016) developed a health and wellbeing framework to guide the implementation of the SDG with a hope that health sector could benefit from it. This is highly significant because not only the framework is connected to health and non-health sector but also the Goals are connected to other sectors linking Goals, targets, and indicators to social, economic, environment, and health determinants (Nunes et al. 2016).

\section{Professional Development and Economic Growth}

Professional development is one of the ultimate factors that enhance human capacity, marketing power, productivity, creativity, better and successful entrepreneurship, and technological advances (Mat et al. 2015). Because of significant linkages between professional development and economic development, it plays a critical role in securing socioeconomic growth and development and eventually can lead to the achievements of the SDGs. World Bank argues that professional development opportunities for those both in and out of work, such as flexible learning opportunities at universities and adult learning programs, enable labor market to adjust to the future work (World Bank 2019). In a study on the relationship between human capital investment and economic development in Sabah, Malaysia, Mat et al. (2015) found that there is a positive relationship between human capital investment and economic development. A similar finding was found by Jalil and Idrees (2013), in which different levels of education influence economic growth and development positively. They suggested that investment in education is essential as it brings people's prosperity, economic well-being, and happiness.

\section{Professional Development and Environment}

Another imperative of the professional development is to achieve environmental sustainability by 2030 that is to focus on developing a key solution for environmental educators for a sustainable environment. Environmental education professionals are pivotal in the success of the 2030 Agenda, because they encourage not only behaviors that can mitigate and solve environmental problems but also help achieving environmental sustainability. Being environmentally sustainable and resilient means it can benefit in many ways: building sustainable communities, better health and well-being, better energy efficiency and resilient infrastructure, building better safety and resilience, and most importantly, building sustainable economy (e.g., saving money) (Manno 2017; Muller and Schader 2017). Yuan et al. (2017) conducted a study on environmental educators from 25 colleges in Taiwan to test whether people would improve their care for the environment positively or negatively. Yuan et al. (2017) found a positive correlation between care for environment and environmental sustainability, it thus contributed significantly to professional development and sustainable environment. Professional development in the environmental sector has a significant role in 
achieving a sustainable and resilient environment Goal by 2030 .

\section{Professional Development and Human Rights}

The concern in professional development in SDGs is learning about human rights and how to address these rights for all. This is pivotal for both the professional development and the achievement of SDGs, because the relationship between human rights and SDGs are mutualistic, meaning they both work together and benefit each other. More importantly, from the legal profession point of view, Danish Institute for Human Rights (2018) estimated that more than $90 \%$ of the global Goals framework targets is associated with international and regional human rights instruments and labor standards. Theoretically, $90 \%$ of the SDGs is linked to the developed and developing nations' human rights instruments.

To reinforce the linkages between professional development, human rights, and SDGs, the professional development has a framework, namely the Universal Declaration of Human Rights (UDHR), to guide the implementation of the SDGs.

The UDHR proclaimed that recognition of the inherent dignity and of the equal and inalienable rights of all human beings is freedom, justice, and peace (United Nations 2015, p. 1). The linkages between professional development, human rights, and SDGs are carefully designed with a purpose of achieving Development Agenda by 2030. The professional development sector should use suitable framework to guide their way forward in addressing economic, social, and environmental concerns vexing the legal profession and Goals. For example, to date, the establishment of the National Human Rights Institutions and its Merida Declaration by the Permanent Mission of Denmark to the United Nations in Geneva indicated that professional development on human rights plays a key role in the implementation of the 2030 Agenda (Jensen 2019).

\section{Factors Affecting Contemporary Trends in Professional Development}

Despite significant linkages between professional development and SDGs, the professional development may hamper its progress towards achieving global Goals due to the impacts of two major factors: globalization and Information and Communication Technology (ICT). In a study on the impact of globalization on teachers in Turkey by Canli and Demirtaş (2018) and economic growth globally by Samimi and Jenatabadi (2014), they found that globalization has influences teaching profession positively, especially in the professional sector so that it is possible to help them achieve the Development Agenda by 2030. These positive effects may include but are not limited to better education, health, economy, environment, trade, technology, marketing, employment, and infrastructure due to the impacts of innovation and cutting-edge technologies (Canli and Demirtaş 2018). In spite of several positive influences of globalization on professional development, there are however many adverse effects as well. Such negative effects include the destruction of local cultures and traditions by civilization (e.g., western culture) and adaptation to the new model and innovative idea in the sense that it takes time for the professional development sector to adjust since it costs a lot of money and time (Canli and Demirtaş 2018).

The other factor that affects contemporary trends in the professional development sector is ICT changes. The rapid development of ICT has largely enhanced the quality of sustainable and resilient professional development as they are the key solution to develop better human resource management with the aim to have a better workforce that would be able to contribute significantly to the achievements of the 2030 Agenda. The ICT and professional development are considered to be important prerequisites for accelerating global Agenda by allowing major structural changes in the professional development. According to Hussain (2018), there are two equally important reasons for integrating ICT in professional development. First, labor force must become familiar with the use of ICT, since all jobs in the society in 
the future will be dependent on it. Second, ICT must be used in the professional development sector as a mean to improve its quality and make it more effective. For example, the launching of 5G by China has prompted professional development sector to advance in a health care setting and better resilient and sustainable infrastructure and better economy (Li and Woo 2019). According to $\mathrm{Li}$ and Woo (2019), the limitations for ICT in professional development are human capacity, resources, and costs.

\section{Professional Development and Sustainable Development}

Professional development and sustainable development are closely intertwined and both are inseparable. Professional development can help achieving sustainable development and sustainable development can promote professional development. Professional development enhances the quality of professionals or skilled labor force in an organization or a country through access to education and training. It enhances professional knowledge, skills, competence, and effectiveness. Professional development leads to increased efficiency and productivity of workforce in an economy and in turn helps building human resource development in a country, the hallmark of the 2030 Development Agenda.

According to Redman et al. (2018), the professional development and sustainable development are dependent factors or covariate, meaning these two variables or cofactors are positively related to one way or another and they move together in the same direction. To test the relationship between professional development and sustainable development, a study was conducted with 246 teachers in the Arizona State University, and the study found that education for sustainable development has impacted $92 \%$ of teachers' perceptions on sustainability positively (Redman et al. 2018). Consequently, this result called on all stakeholders to adopt such a program as professional development (e.g., continuing education) for sustainable development, globally.
Based on the previous discussions, it is clear that professional development is the main driver in achieving SDGs. As mentioned earlier, the 16 SDGs are falling under five sectors: education, health, economic, environment, and human rights, and SDG 17 is designed for global partnership and it encompasses all other Goals in the SDG framework.

\section{Challenges to Professional Development}

Teacher professional development is a necessary element in educational change. Professional development is undergoing fast changes with the technological changes. Technophobia in professional development sector is a major issue (Bernadine 2019). However, many people lack access to technology, resulting in new form of exclusion often described as "digital divide." Inclusive development is a prerequisite of success of development or sustainable development. The "digital divide" is a challenge to successful professional development. Continuous professional development (CPD) can help teachers unlock barriers to learning. One of the challenges for the effectiveness of continuous professional development is that the educators often see it as a topdown approach run by and cater to the goals of the educational managers rather than the needs of the staff. Another challenge to the effectiveness of the professional development is it being delivered in multiple ways due to lack of national strategy and framework. Limited resources, lack of implementation plan, wide range of teachers' skills and experiences, and poorly designed professional development are some of the challenges in implementing continuous professional development effectively. Besides, a lack of teachers' technological, pedagogical and content knowledge, inadequate infrastructure, linguistic differences, limitations of internet diffusions are some of the challenges in teacher professional development.

Professional development of teachers requires a lifelong learning approach. A systematic professional development also needs lifelong professional processes. An absence of such a process in teacher professional development not only 
challenges quality education but also a challenge to achieving SDGs. The major challenges for the implementation of the SDGs through professional development sector are that the professional development itself does not have a clear framework on how each Goal, Target, and Indicator should be achieved by 2030 and beyond. Moreover, there is a lack of knowledge on the linkages between professional development and SDGs (Anåker et al. 2015; Duane et al. 2019).

\section{Way Forward}

Professional development's main concern is about education and training. There is a need to increase training and education infrastructure to cater to professional development sector. There is a need for awareness program in understanding the linkages between professional development and SDGs and enhancing knowledge of use of ICT tools. Providing the educators access to the ICT tools and training on ICT will not only bridge the "digital divide" but also promote effective professional development. A clear action plan in education, health, economic, environmental, and human rights sector is required. Moreover, a framework to guide the professional development sector that is aligned to the 2030 Development Agenda is a way forward.

\section{Conclusion}

Quality education is fundamental in achieving sustainable development. Professional development in all sectors especially in education sector is critical in achieving quality education and in turn the SDGs and sustainable development. Education, health, economic, environmental, and human rights sector are critical sectors that clearly orchestrated in favor of SDGs. Professional development of teachers, health professionals, environment educators, and human right activists requires a lifelong learning approach. The Information and Communication Technology (ICT) has set in motion on deeper and lifelong learning processes. There is a greater need to provide the educators access to the ICT tools and training which will promote an effective professional development. Moreover, there is a greater need to integrate professional development of various sectors and implementation of a clear framework that guide professional development on a sustainable way. In the absence of sound professional development, the SDGs and the 2030 Development Agenda may not be achieved successfully in building a pathway which is more resilient and sustainable.

\section{Cross-References}

\author{
Engaged Learning \\ Informal Education/Nonformal Education \\ - Informal Workplace Learning \\ Lifelong Learning \\ Skill Building
}

\section{References}

Anåker A, Nilsson M, Holmner Å, Elf M (2015) Nurses' perceptions of climate and environmental issues: a qualitative study. J Adv Nurs 71(8):1883-1891

Arslan FY (2019) The role of lesson study in teacher learning and professional development of EFL teachers in Turkey: a case study. TESOL J 10(2):e00409

Aslam S, Delgado-Angulo EK, Bernabé E (2017) Perceived learned skills and professional development of graduates from a master in dental public health programme. Eur J Dent Educ 21(1):1-5

Ayeleke RO, North N, Wallis KA, Liang Z, Dunham A (2016) Outcomes and impact of training and development in health management and leadership in relation to competence in role: a mixed-methods systematic review protocol. Int J Health Policy Manag 5(12):715-720. https://doi.org/10.15171/ijhpm.2016.138

Baldwin K (2017) When politicians listen to scientists, we all benefit [Online]. The Conversation, Parkville. http:// theconversation.com/when-politicians-listen-to-scient ists-we-all-benefit-74443. Accessed 29 May 2019

Bernadine GGK (2019) Challenges faced by educators in the implementation of Continuing Professional Teacher Development (CPTD): Gauteng Province. In: Monyai RB (ed) Teacher education in the $21 \mathrm{st}$ century. IntechOpen, London

Blau G, Hill TL, Snell C, Atwater C, Halbert T et al (2016) Testing the relationship of gender and business major to professional development behaviors and expected employment. J Educ Bus 91(5):274-279 
Canli S, Demirtaş H (2018) The impact of globalisation on teaching profession: the global teacher. J Educ Train Stud 6(1):80-95

CDC (Centre for Disease Control and Prevention) (2018) Professional development \& training [Online]. CDC, Atlanta. https://www.cdc.gov/healthyschools/ trainingtools.htm. Accessed 28 May 2019

Chams N, García-Blandón J (2019) On the importance of sustainable human resource management for the adoption of sustainable development goals. Resour Conserv Recycl 141:109-122

Coenders F, Verhoef N (2019) Lesson study: professional development (PD) for beginning and experienced teachers. J Prof Dev Educ 45(2):217-230

Donelan H (2016) Social media for professional development and networking opportunities in academia. J Furth High Educ 40(5):706-729

Duane B, Harford S, Ramasubbu D, Stancliffe R, PasdekiClewer E et al (2019) Environmentally sustainable dentistry: a brief introduction to sustainable concepts within the dental practice. Br Dent J 6(4):292-295

Duffy R, Reid L, Dik B (2010) Spirituality, religion, and career development: implications for the workplace. J Manag Spiritual Relig 7(3):209-221

Education Development Trust (2016) A study on children with disabilities and their right to education: Madagascar. Education Development Trust, Reading

EvoLLLution (2012) Lifelong education and labour market needs. Destiny Solutions Inc., Toronto

Fernandez C (2002) Learning from Japanese approaches to professional development: the case of lesson study. J Teach Educ 53(5):393-405

Froude JA (2014) The nemesis of faith. Amazon Digital Services LLC, London

Fuertes-Camacho TM, Graell-Martín M, Fuentes-Loss M, Balaguer-Fàbregas CM (2019) Integrating sustainability into higher education curricula through the project method, a global learning strategy. Sustainability 11(3):767

Garet MS, Porter AC, Desimone L, Birman BF, Yoon KS (2001) What makes professional development effective? Results from a national sample of teachers. Am Educ Res J 38(4):915-945

Giezen M, Balikci S, Arundel R (2018) Using remote sensing to analyse net land-use change from conflicting sustainability policies: the case of Amsterdam. ISPRS Int J Geo Inf 7(9):381

Giri K, Frankel N, Tulenko K, Puckett A, Bailey R et al (2012) Keeping up to date: continuing professional development for health workers in developing countries. CapacityPlus technical brief. IntraHealth International, Washington

Gore J, Lloyd A, Smith M, Bowe J, Ellis H et al (2017) Effects of professional development on the quality of teaching: results from a randomised controlled trial of Quality Teaching Rounds. Teach Teach Educ 68:99-113

Gusky TR, Huberman M (1995) Professional development in education: new paradigms and practices. Teachers College Press, New York
Havea PH (2019) Climate change impact on livelihood, health and well-being: a mixed method approach. The Unversity of the South Pacific, Suva

Honeck E, Castello R, Chatenoux B, Richard J-P, Lehmann A et al (2018) From a Vegetation Index to a Sustainable Development Goal indicator: forest trend monitoring using three decades of Earth observations across Switzerland. ISPRS Int J Geo Inf 7(12):455

Hussain Z (2018) The effect of ICT-based learning on students' vocabulary mastery in junior high schools in Bandung. Int J Educ 10(2):149-156

ICSA (Institute of Chartered Secretaries and Administrators) (2019) Formal and informal CPD [Online]. Institute of Chartered Secretaries and Administrators, London. https://www.icsa.org.uk/professional-development/cpd/ formal-and-informal-cpd. Accessed 28 May 2019

Ionela AM (2012) The role of lifelong learning in the growth of employment and labour efficiency. The case of Romania. Procedia Soc Behav Sci 46:4399-4403

Jalil A, Idrees M (2013) Modeling the impact of education on the economic growth: evidence from aggregated and disaggregated time series data of Pakistan. Econ Model 31:383-388

Jensen SLB (2019) The role of National Human Rights Institutions in the implementation of the 2030 Agenda. The Danish Institute for Human Rights, Copenhagen

Körfgen A, Förster K, Glatz I, Maier S, Becsi B et al (2018) It's a hit! Mapping Austrian research contributions to the Sustainable Development Goals. Sustainability 10(9):3295

Lewis C (2016) Compulsory professional development for Members of Parliament. In: Lewis C, Coghill K (eds) Parliamentarians' professional development. Public administration, governance and globalization. Springer, Cham, pp 101-119

Li S, Woo S (2019) China grants 5G commercial licenses to its biggest wireless carriers [Online]. Wall Street J. https:// www.wsj.com/articles/china-grants-5g-commercial-licen ses-to-its-biggest-wireless-carriers-11559825246. Accessed 15 June 2019

Maclean RDI (1992) Teachers' career and promotion patterns: a sociological analysis. Falmer Press, London

Manno J (2017) Environmental sustainability/sufficiency. In: Denemark RA, Marlin-Bennett R (eds) The international studies encyclopedia. Wiley-Blackwell, Oxford, UK

Mat NA, Mansur K, Mahmud R (2015) The relationship between human capital investment and economic development in Sabah. Malays J Bus Econ 2(1):83-107

Muller A, Schader C (2017) Efficiency, sufficiency, and consistency for sustainable healthy food. Lancet Planet Health 1(1):e13-e14

Murphy-Latta T (2011) A comparative study of professional development utilizing the Missouri Commissioner's Award of Excellence and indicators of student achievement. Proquest, Umi Dissertation Publishing, Michigan

Nilsson A (2010) Vocational education and training: an engine for economic growth and a vehicle for social inclusion? Int J Train Dev 14(4):251-272

NPDCI (National Professional Development Center on Inclusion) (2008) What do we mean by professional 
development in the early childhood field? The University of North Carolina, Chapel Hill

Nunes AR, Lee K, O'Riordan T (2016) The importance of an integrating framework for achieving the Sustainable Development Goals: the example of health and wellbeing. BMJ Glob Health 1:e000068

OECD (Organisation for Economic Co-operation and Development) (2009) Creating effective teaching and learning environments: first results from TALIS. OECD, Paris

Opperman C, Liebig D, Bowling J, Johnson CS (2018) Measuring return on investment for professional development activities: 2018 updates. J Nurses Prof Dev 36(6):303-312

Postholm MB (2012) Teachers' professional development: a theoretical review. Educ Res 54(4):405-429

Proto E (2016) Are happy workers more productive? IZA World Labor 315:1-8

Redman E, Wiek A, Redman A (2018) Continuing professional development in sustainability education for K-12 teachers: principles, programme, applications, outlook. J Educ Sustain Dev 12(1):59-80

Samimi P, Jenatabadi HS (2014) Globalization and economic growth: empirical evidence on the role of complementarities. PLoS One 9(4):e87824

Sexana V (ed) (2012) Contemporary trends in education: a handbook for educators. Pearson, Delhi

Silvester J, Wyatt M (2015) Developing strong and diverse political leaders. Psychologist 28(5):370

Smith C, Johnson CS (2018) Preparing nurse leaders in nursing professional development: theories applied to leadership in nursing professional development. J Nurses Prof Dev 34(1):38-40
Smith MH, Worker SM, Schmitt-McQuitty L, Meehan CL, Lewis KM et al (2017) Prevalent approaches to professional development in state 4-H programs. J Ext 55(4): Article 4RIB2

Stein MK, Smith MS, Silver EA (1999) The development of professional developers: learning to assist teachers in new settings in new ways. Harv Educ Rev 69(3):237-269

Subedi B (2006) Preservice teachers' beliefs and practices: religion and religious diversity. Equity Excell Educ 39(3):227-238

The Danish Institute for Human Rights (2018) Human rights and the 2030 Agenda for Sustainable Development. The Danish Institute for Human Rights, Copenhagen

UNDP (United Nations Development Programme) (2015) Sustainable Development Goals (SDGs). UNDP, New York

United Nations (2015) Universal Declaration of Human Rights. United Nations, New York

Van den Homberg M, Susha I (2018) Characterizing data ecosystems to support official statistics with open mapping data for reporting on Sustainable Development Goals. ISPRS Int J Geo Inf 7(12):456

Wilson AB, Furman J, Orozco JM (2019) Associations between professional development benefits and PA career satisfaction. J Am Acad Physician Assist 32(2):36-40

World Bank (2019) World Development Report: the changing nature of work. World Bank, Washington, DC

Yuan K-S, Wu T-J, Chen H-B, Li Y-B (2017) A study on the teachers' professional knowledge and competence in environmental education. EURASIA J Math Sci Technol Educ 13(7):3163-3175 